\title{
PENGARUH PENAMBAHAN BIJI LAMTORO GUNG (Leucaena leucocephala) PADA PROSES FERMENTASI TEMPE
}

\author{
Influence of Seed Addition Gung Leucaena (Leucaena leucocephala) At Tempe \\ Fermentation Process \\ Deny Utomo ${ }^{1)}$, Nurul Qomariyah ${ }^{1)}$ \\ ${ }^{1)}$ Prodi Ilmu dan Teknologi Pangan, Universitas Yudharta Pasuruan \\ *Email : denyut369@gmail.com
}

\begin{abstract}
In general people use soy as an ingredient manufacture of tempeh, tempeh is increasing demand resulted in a growing number of imported soybeans. Businesses that can be done to overcome this is by replacing or mixing the raw materials (soybeans) with other materials. One soy substitutes are gung lamtoro seed. Product diversification tempeh can be done by adding a gung lamtoro in soybean tempeh. This study aims to determine the effect of the proportion of soybean seeds: lamtoro gung against tempeh fermentation time and quality. This study uses a randomized block design (RAK) Factorial which consists of three factors, namely the percentage of seed treatment lamtoro gung $10 \%, 15 \%$ and $20 \%$ and fermentation time 18 Hours and 36 Hours. The data obtained were analyzed by ANOVA and Duncan's Multiple Range Test continued (DMRT) 5\%. Based on physicochemical analysis results obtained tempeh lamtoro that consumers preferred that the AlB2 treatment (percentage of seeds lamtoro gung $10 \%$ and fermentation time 36 hours) with the following qualities: The water content of $70.57 \%, 23.43 \%$ protein content, fat content $5,46 \%$, carbohydrates $10.34 \%$, and based on the results obtained by organoleptic tests tempeh lamtoro that consumers preferred that the A1B1 treatment (percentage of seeds lamtoro gung $10 \%$ and fermentation time 18 hours) with the following characteristics: A taste value 4.75 (Liking); A value of 4.35 aroma (Liking); A color value of 4.75 (Liking); A texture value of 3.95 (Neutral).
\end{abstract}

Keywords : Soybean, tempe, seed gung Leucaena, fermentation

\begin{abstract}
ABSTRAK
Pada umumnya masyarakat menggunakan kedelai sebagai bahan pembuatan tempe, permintaan tempe semakin meningkat mengakibatkan semakin banyak impor kedelai. Usaha yang dapat dilakukan untuk mengatasi hal tersebut yaitu dengan mengganti atau mencampur bahan baku (kedelai) dengan bahan yang lain. Salah satu bahan pengganti kedelai adalah biji lamtoro gung. Diversifikasi produk tempe dapat dilakukan dengan cara menambahkan lamtoro gung dalam tempe kedelai. Penelitian ini bertujuan untuk mengetahui pengaruh proporsi biji kedelai : lamtoro gung terhadap lama fermentasi dan kualitas tempe. Penelitian ini menggunakan rancangan Acak Kelompok (RAK) Faktorial dimana terdiri dari 3 faktor Perlakuan yaitu prosentase biji lamtoro gung 10\%, 15\% dan 20\% dan lama fermentasi 18 Jam dan 36 Jam. Data yang diperoleh dianalisis dengan uji sidik ragam dan dilanjutkan uji Jarak Berganda Duncan (DMRT) $5 \%$. Berdasarkan hasil analisa fisikokimia diperoleh tempe lamtoro yang disukai konsumen yaitu pada perlakuan A1B2 (prosentase biji lamtoro gung $10 \%$ dan lama fermentasi 36 jam) dengan kualitas sebagai berikut : kadar Air 70,57\%, kadar protein 23,43 \%, kadar lemak 5,46 \%, kadar karbohidrat 10,34\%, dan berdasarkan hasil uji organoleptik diperoleh tempe lamtoro yang disukai konsumen yaitu pada perlakuan A1B1 (Prosentase biji lamtoro gung 10\% dan lama fermentasi 18 jam) dengan karakteristik sebagai berikut : nilai kesukaan rasa 4,75 (Menyukai); nilai kesukaan aroma 4,35 (Menyukai); nilai kesukaan warna 4,75 (Menyukai); nilai kesukaan tekstur 3,95 (Netral).
\end{abstract}

Kata Kunci : Kedelai, Tempe, Biji Lamtoro Gung, Fermentasi 


\section{PENDAHULUAN}

Kebutuhan akan pangan semakin meningkat dengan bertambahnya jumlah penduduk. Berbagai jenis pangan diproduksi dengan meningkatkan kuantitas serta kualitasnya untuk memenuhi kebutuhan pangan masyarakat. Selain dengan meningkatkan jumlahnya, pemenuhan kebutuhan pangan juga dapat dilakukan dengan mengoptimalkan penggunaan sumber bahan pangan yang beraneka ragam. Hal ini dilakukan sebagai upaya diversifikasi pangan dengan memanfaatkan sumber daya pangan lokal.

Bahan pangan berprotein nabati yang banyak dipergunakan sebagai bahan dasar fermentasi pangan adalah: kedelai atau jenis kacang-kacangan lain, seperti kacang tanah, kara benguk dan kacang gude. Di antara bahan-bahan tersebut, kedelai paling sering digunakan sebagai bahan dasar makananmakanan fermentasi dibeberapa negara, karena kadar proteinnya yang sangat tinggi (Kasmidjo, 1990). Salah satu produk fermentasi berbahan dasar kedelai di Indonesia adalah tempe.

Tempe merupakan bahan makanan hasil fermentasi kacang kedelai atau jenis kacang-kacangan lainnya menggunakan jamur Rhizopus oligosporus dan Rhizopus oryzae. Tempe umunya dibuat secara tradisional dan merupakan sumber protein nabati. Tempe mengandung berbagai macam nutrisi yang diperlukan oleh tubuh seperti protein, lemak, karbohidrat dan mineral. Beberapa penelitian menunjukkan bahwa zat gizi tempe lebih mudah dicerna, diserap dan dimanfaatkan tubuh. Hal ini dikarenakan kapang yang tumbuh pada kedelai menghidrolisis senyawa-senyawa kompleks menjadi senyawa sederhana yang mudah dicerna oleh manusia (Kasmidjo, 1990).

Diversifikasi pangan merupakan salah satu instrumen penting untuk mengurangi tekanan atas permintaan dan harga pangan. Diversifikasi pangan dimaksudkan untuk memperoleh keragaman zat gizi sekaligus melepas ketergantungan masyarakat terhadap satu jenis pangan pokok tertentu (Marwanti, 2012).

Diversifikasi produk tempe dapat dilakukan dengan cara menambahkan biji lamtoro gung tanpa kulit dalam tempe kedelai. Penambahan biji lamtoro tanpa kulit diharapkan dapat mengurangi proporsi penggunaan kedelai sebagai bahan baku dalam pembuatan tempe.

Lamtoro gung merupakan tanaman yang dapat tumbuh baik dan banyak ditemui di berbagai tempat di Indonesia. Lamtoro gung telah dimanfaatkan oleh masyarakat sebagai pohon peneduh, pencegah erosi, sumber kayu bakar dan pakan ternak. Biji lamtoro gung dapat dijadikan sebagai bahan makanan manusia yang biasanya hanya dalam bentuk makanan yang disebut botok, tetapi biji lamtoro gung ini kurang diminati dan terbuang sia-sia sehingga biji lamtoro gung merupakan salah satu limbah yang kurang dimanfaatkan manusia (Anonymous, 2015b).

Pemanfaatan biji lamtoro gung yang sangat terbatas ini sangat disayangkan karena biji lamtoro gung mengandung protein tinggi. Pada hasil penelitian Anny Rahayu dkk (1993) menunjukkan bahwa kecap yang menggunakan biji lamtoro gung mengandung protein sebesar $20,86 \%$. Hal ini menunjukkan bahwa kandungan protein lamtoro gung sangat tinggi, demikian juga terhadap produk pangan yang dihasilkannya. Untuk itu perlu dilakukan penelitian penambahan biji lamtoro gung pada tempe, supaya dapat memanfaatkan dan meningkatkan nilai tambah dari biji lamtoro gung. Tujuan penelitian adalah mengetahui prosentase dan lama proses fermentasi biji lamtoro gung yang tepat serta sifat fisiko kimia pada pembuatan tempe, mengetahui prosentase dan lama proses fermentasi biji lamtoro gung yang tepat serta uji organoleptik pada pembuatan tempe dan mMengetahui kombinasi perlakuan manakah yang terbaik terhadap sifat fisiko, kimia dan uji organoletik pada pembuatan tempe biji lamtoro gung. 


\section{BAHAN DAN METODE}

\section{Bahan dan alat}

Bahan yang diguakan dalam penelitian ini adalah kedelai yang diperoleh dipasar Sukorejo Pasuruan, biji lamtoro gung, air, ragi, tepung tapioca. Peralatan yang digunakan dalam penelitian ini adalah : timbangan, bak plastic, panic,baskom plastic, pengaduk, kompor, LPG, cetakan

\section{Rancangan percobaan}

Rancangan percobaan yang dilakukan adalah rancangan acak kelompok (RAK) factorial terdiri dari 3 faktor, factor pertama terdiri dari 3 faktor, factor pertama terdiri dari 3 level dan factor kedua terdiri dari 2 level sehingga didapat 6 perlakuan kombinasi dengan ulangan sebanyak 3 kali. Adapun factor perlakuan yang digunakan adalah presentase biji lamtoro gung dalam tempe (A) dan lama fermentasi tempe campuran biji lamtoro gung (B) dengan tahap sebagai berikut. Faktor A (presentase biji lamtoro gung dalam tempe) terdiri dari 3 level yaitu $\mathrm{A} 1=10 \%, \mathrm{~A} 2=15 \%, \mathrm{~A} 3=20 \%$. Faktor B (lama fermentasi tempe campuran biji lamtoro gung), terdiri dari 2 level yaitu $\mathrm{B} 1=18 \mathrm{Jam}$ dan $\mathrm{B} 2=36 \mathrm{Jam}$

\section{Persiapan biji lamtoro gung}

Sebelum dibuat tempe, biji Lamtoro gung yang sudah dikupas dari polongnya dilakukan proses penjemuran yang dialasi dengan tampah. Biji lamtoro gung dibersihkan dan disortasi sehingga diperoleh biji lamtoro gung yang sudah bersih. Biji lamtoro gung direndam selama 12 jam, kemudian dicuci dan direbus selama 2 jam. Tahapan selanjutnya kulit biji Iamtoro gung dikupas sehingga kulit dan keping biji lamtoro gung terpisah. Keping biji yang sudah terkupas, dicuci dan direndam selama 12 jam yang tujuannya untuk menghilangkan lendir dan menonaktifkan bakteri kontaminan, kemudian keping biji dikukus selama 30-60 menit. Biji lamtoro gung tanpa kulit ditiriskan dan didinginkan.

\section{Pesiapan biji kedelai}

Biji kedelai dibersihkan dari kotoran. Biji kedelai dicuci sampai bersih dalam ember yang berisi air atau air yang mengalir, kemudian biji kedelai direbus sampai kedelai setengah matang selama 30 menit dalam panci. Tahapan selanjutnya dilakukan proses pengelupasan kulit kedelai dengan meremas-remasnya dalam air, kemudian merendam biji kedelai selama 24 jam dengan menggunakan air bersih. Setelah itu, biji kedelai dicuci dan direbus selama 45-60 menit sampai kedelai matang. Setelah matang kedelai diletakkan di atas tampah secara merata untuk ditiriskan dan didinginkan.

\section{Pembuatan tempe lamtoro}

Biji lamtoro gung dan biji kedelai dicampur sesuai perlakuan dan diinokulasi dengan ragi tempe sebanyak 1\% (1 g ragi untuk $100 \mathrm{~g}$ bahan) kemudian diaduk hingga rata. Campuran biji lamtoro gung dan biji kedelai yang telah diberi ragi dibungkus dengan plastik dan diinkubasi selama 18 dan 36 jam.

\section{Pengamatan}

Pegamatan yang dilakukan pada tempe camputan biji lamtoro gung adalah kadar protein, kadar karbohidrat, kadar lemak, kadar ait serta organoleptik meliputi kesukaan terhadap rasa, wana, tekstur dan aroma minimal dilakukan oleh 20 panelis.

\section{Analisis Data}

Analisis ragam dilakukan untuk mengetahui adanya pengaruh perlakuan berapa prosentase campuran biji lamtoro gung pada tempe dan berama lama waktu yang dibutuhkan untuk fermentasi tempe dengan campuran biji lamtoro gung terhadap rasa, warna tekstur dan aroma.Untuk parameter-parameter bersifat kualitatif yaitu kesukaan rasa, warna, tekstur dan aroma dilakukan analisis ragam dengan metode friedman untuk mengetahui perlakuan mana yang berbeda. 


\section{Perlakuan terbaik}

Pengambilan keputusan dilakukan untuk menentukan perlakuan mana yang terbaik untuk prosentase campuran biji lamtoro gung pada tempe dan lama fermenta: i dengan memepertim bangk an ke enam variable tersebut. Penelitian ini menggunakan rancangan Acak Kelompok (RAK) Faktorial dimana terdiri dari 3 faktor Perlakuan yaitu prosentase biji lamtoro gung $10 \%, 15 \%$ dan $20 \%$ dan lama fermentasi 18 Jam dan 36 Jam. Data yang diperoleh dianalisis dengan uji sidik ragam dan dilanjutkan uji Jarak Berganda Duncan (DMRT) $5 \%$.

\section{HASIL DAN PEMBAHASAN}

\section{Kadar protein}

Protein merupakan komponen yang banyak terdapat pada sel tanaman dan hewan. Kandungan protein dalam bahan pangan bervariasi baik dalam jumlah maupun jenisnya. Protein merupakan sumber gizi utama, yaitu sebagai sumber asam amino. Diantaranya terdapat 8 dari 20 asam amino penyusun protein yang merupakan zat nutrisi esensial yang diperlukan tubuh yaitu lisin, triptofan, fenilalanin, metionin, treonin, leusin, isoelusin dan valin. Disamping sebagai sumber gizi, protein juga memberikan sifat fungsional yang penting dalam membentuk karakteristik produk pangan (Andarwulan dkk., 2011).

Berdasarkan analisa kadar protein yang dilkukan pada tempe lamtoro diperoleh rata-rata kadar protein antara $13,41 \%$ sampai $23,43 \%$, berdasarkan analisa sidik ragam kadar protein tempe lamtoro bahwa perlakuan prosentase biji lamtoro gung (A) dan lama fermentasi tempe menunjukkan pengaruh sangat berbeda nyata (lampiram 4). Rata - rata kadar protein berbagai kombinasi perlakuan dapat dilihat pada Tabel 1.
Tabel 1. Rata-rata kadar protein (\%) tempe lamtoro

\begin{tabular}{|c|c|c|c|}
\hline \multirow{3}{*}{$\begin{array}{c}\text { Lama } \\
\text { Fermentasi }\end{array}$} & \multicolumn{3}{|l|}{ Prosentase } \\
\hline & $\begin{array}{c}\text { Biji } \\
\text { Lamtoro }\end{array}$ & rata & nM\% \\
\hline & Gun & Protein & \\
\hline \multirow{3}{*}{18 Jam } & $10 \%$ & $17,27 b$ & 3,28 \\
\hline & $15 \%$ & $16,05 a$ & 3,22 \\
\hline & $20 \%$ & $13,41 \mathrm{a}$ & 2,98 \\
\hline \multirow{3}{*}{$36 \mathrm{Jam}$} & $10 \%$ & $23,43 d$ & 3,36 \\
\hline & $15 \%$ & $21,66 \mathrm{c}$ & 3,33 \\
\hline & $20 \%$ & $15,89 \mathrm{a}$ & 3,13 \\
\hline
\end{tabular}

Histagram rata-rata kadar protein pada berbagai perlakuan lama fermentasi dan prosentase biji lamtoro gung disajikan pada Gambar 1. Gambar 1 menunjukkan bahwa kadar protein tertinggi diperoleh pada kombinasi perlakuan A1B2 (prosentase biji lamtoro gung sebesar $15 \%$ dan lama fermentasi 36 jam) yaitu sebesar 23,43\% sedangkan kadar protein terendah diperolehpada kombinasi perlakuan A3B1 (prosentase biji lamtoro gung sebesar $20 \%$ dan lama fermentasi 18 jam) yaitu sebesar $13,41 \%$

\section{Rerata Kadar Protein Tempe Lamtoro}

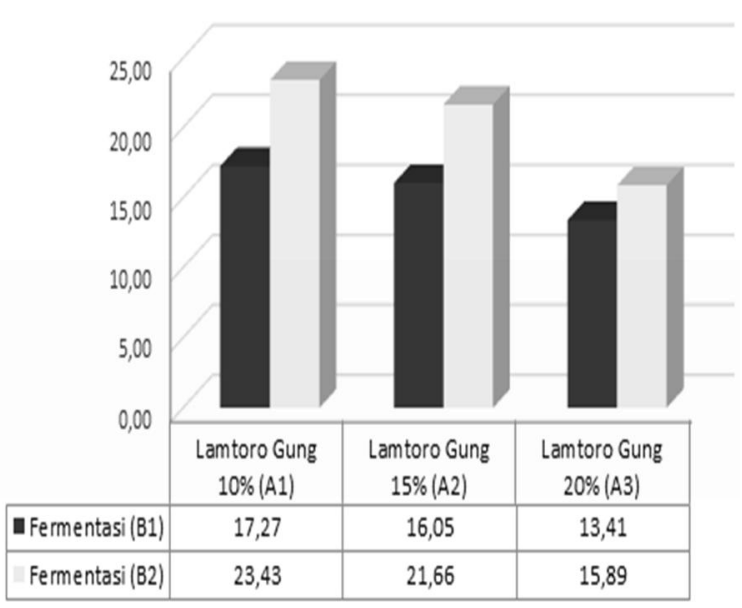

Gambar 1. Rerata kadar protein (\%) tempe lamtoro

Kadar protein tempe lamtoro cenderung mengalami kenaikan dengan meningkatnya waktu fermentasi, hasil tersebut sesuai dengan pendapat Kasmidjo (1990), selama proses fermentasi terjadi 
perubahan jumlah kandungan asam-asam amino yang secara keseluruhan jumlah asam-asam amino mengalami kenaikan setelah proses fermentasi, semakin sedikit prosentase biji lamtoro gung yang digunakan maka kadar protein pada tempe lamtoro juga semakin meningkat hal ini terjadi karena kandungan protein pada kedelai lebih besar dari pada kandungan protein dalam biji lamtoro gung.

Jamur yang tumbuh pada kedelai menghasilkan enzim-enzim pemecah senyawa kompleks. Rhizopus oligosporus menghasilkan enzim-enzim protease. Perombakan senyawa kompleks protein menjadi senyawa-senyawa lebih sederhana yaitu asam amino yang penting dalam fermentasi tempe, dan merupakan salah satu faktor utama penentu kualitas tempe, yaitu sebagai sumber protein nabati yanag memiliki nilai cerna tinggi karena lebih mudah untuk diserap dan dimanfaatkan oleh tubuh secara langsung (Santoso, 2005).

\section{Kadar Karbohidrat}

Karbohidrat merupakan komponen bahan pangan yang merupakan sumber energi utama dan serat makanan yang mempengaruhi proses fisiologis tubuh. Karbohidrat mempunyai sifat fungsional yang penting dalam proses pengolahan makanan, seperti sebagai bahan pengisi, pengental, penstabil emulsi pengikat air, pembentuk flavor, aroma dan tekstur. Karbohidrat juga penting sebagai sumber pemanis alami, bahan baku proses fermentasi, berperan dalam menentukan karakteristik reologi dari berbagai jenis bahan atau produk pangan (Winarno, 2004).

Berdasarkan analisa kadar karbohidrat yang dilkukan pada tempe lamtoro diperoleh rata-rata kadar karbohidrat antara 5,69\% sampai $14,51 \%$ berdasarkan analisa sidik ragam kadar protein tempe lamtoro bahwa perlakuan prosentase biji lamtoro gung (A) dan lama fermentasi tempe (B) menunjukkan pengaruh sangat berbeda nyata. Rata-rata kadar protein berbagai kombinasi perlakuan dapat dilihat pada Tabel 2.
Tabel 2. Rata-rata kadar karbohidrat (\%) tempe lamtoro

\begin{tabular}{cccc}
\hline Lama & $\begin{array}{c}\text { Prosenta } \\
\text { se Biji } \\
\text { Lermentasi } \\
\text { Gung }\end{array}$ & $\begin{array}{c}\text { Rerata } \\
\text { Kadar } \\
\text { Karbohi } \\
\text { drat }\end{array}$ & $\begin{array}{c}\text { DMRT } \\
5 \%\end{array}$ \\
\hline \multirow{3}{*}{ 18 Jam } & $10 \%$ & $14,51 \mathrm{~d}$ & 3,36 \\
& $15 \%$ & $10,83 \mathrm{c}$ & 3,33 \\
& $20 \%$ & $9,41 \mathrm{~b}$ & 3,22 \\
36 Jam & $10 \%$ & $10,34 \mathrm{~b}$ & 3,28 \\
& $15 \%$ & $7,17 \mathrm{a}$ & 3,13 \\
& $20 \%$ & $5,69 \mathrm{a}$ & 2,98 \\
\hline
\end{tabular}

Histagram rata-rata kadar karbohıdrat pada berbagai perlakuan lama fermentasi dan prosentase biji lamtoro gung disajikan pada Gambar 2.

Rerata Kadar Karbohidrat Tempe Lamtoro

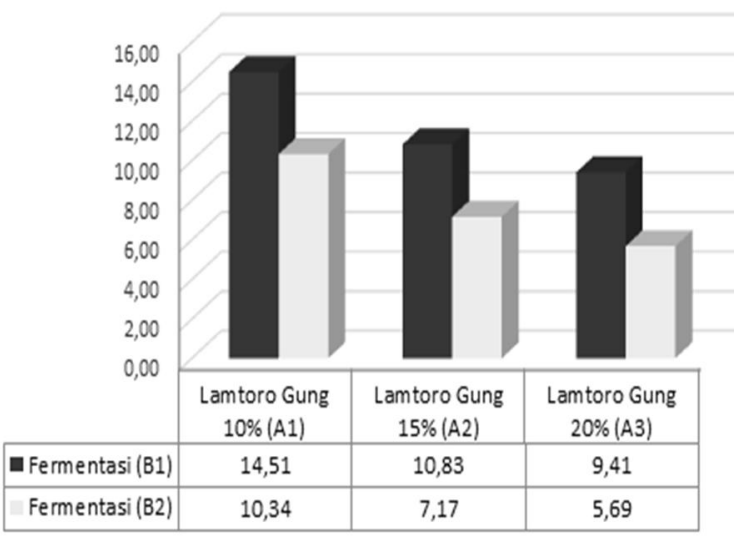

Gambar 2. Rerata kadar karbohidrat (\%) tempe lamtoro

Gambar 2 menunjukkan bahwa kadar karbohidrat tertinggi diperoleh pada kombinasi perlakuan A1B1 (prosentase biji lamtoro gung sebesar $10 \%$ dan lama fermentasi 18 jam) yaitu sebesar 14,51\% sedangkan kadar karbohidrat terendah diperoleh pada kombinasi perlakuan A3B2 (prosentase biji lamtoro gung sebesar $20 \%$ dan lama fermentasi 36 jam) yaitu sebesar $5,69 \%$.

Dari Gambar 2 diketahui bahwa semakin lama fermentasi maka kadar karbohidrat pada sampel tempe lamtoro semakin menurun, hal ini dikarenakan 
karbohidrat yang telah banyak dimanfaatkan oleh mikroba sebagai nutrisi untuk hidup selama proses fermentasi berlangsung. Semakin sedikit prosentase biji lamtoro gung yang digunakan maka kadar karbohidrat pada tempe lamtoro juga semakin meningkat hal ini terjadi karena kandungan karbohidrat pada kedelai lebih besar dari pada kandungan protein dalam biji lamtoro gung.

\section{Kadar Lemak}

Lemak atau minyak memiliki peranan yang sangat besar dalam kehidupan manusia. Lemak atau minyak adalah salah satu komponen gizi utama sebagai penyumbang energi dalam tubuh. Konversi energi dari lemak yang mencapai $9 \mathrm{kkal} / \mathrm{g}$ jauh lebih efisien dibandingkan dengan protein dan karbohidrat yang masing-masing hanya mencapai $4 \mathrm{kkal} / \mathrm{g}$. Lemak atau minyak merupakan senyawa yang larut dalam pelarut organik tetapi tidak larut air sifat kelarutan lipid sangat tergantung pada struktur umumnya dan ini menjadi dasar penggolongan jenis lipid (Budijanto dkk, 2001).

Berdasarkan analisa kadar lemak yang dilkukan pada tempe lamtoro diperoleh ratarata kadar lemak antara 6,13\% sampai 8,23 $\%$ berdasarkan analisa sidik ragam kadar protein tempe lamtoro bahwa perlakuan prosentase biji lamtoro gung (A) dan lama fermentasi tempe (B) menunjukkan pengaruh sangat berbeda nyata (lampiram 6). Rata-rata kadar lemakberbagai kombinasi perlakuan dapat dilihat pada Tabel 3.

Tabel 3 Rata-rata kadar Lemak (\%) tempe lamtoro

\begin{tabular}{cccc}
\hline $\begin{array}{c}\text { Lama } \\
\text { Fermentasi }\end{array}$ & $\begin{array}{c}\text { Prosentase } \\
\text { Biji } \\
\text { Lamtoro } \\
\text { Gung }\end{array}$ & $\begin{array}{c}\text { Rerata } \\
\text { Kadar } \\
\text { Lemak }\end{array}$ & $\begin{array}{c}\text { DMRT } \\
5 \%\end{array}$ \\
\hline \multirow{3}{*}{$18 \mathrm{Jam}$} & $10 \%$ & $6,18 \mathrm{f}$ & 3,36 \\
& $15 \%$ & $5,75 \mathrm{e}$ & 3,33 \\
& $20 \%$ & $5,24 \mathrm{~d}$ & 3,22 \\
36 Jam & $10 \%$ & $5,46 \mathrm{c}$ & 3,28 \\
& $15 \%$ & $4,84 \mathrm{~b}$ & 2,98 \\
& $20 \%$ & $4,59 \mathrm{a}$ & 3,13 \\
\hline
\end{tabular}

Histagram rata-rata kadar lemak pada berbagai perlakuan lama fermentasi dan prosentase biji lamtoro gung disajikan pada Gambar 3. Gambar menunjukkan bahwa kadar lemak tertinggi diperoleh pada kombinasi perlakuan prosentase biji lamtoro gung sebesar $15 \%$ dan lama fermentasi 36 jam yaitu sebesar 8,23\% sedangkan kadar karbohidrat terendah diperoleh pada kombinasi perlakuan prosentase biji lamtoro gung sebesar $10 \%$ dan lama fermentasi 18 jam yaitu sebesar $6,13 \%$.

\section{Rerata Kadar Lemak Tempe Lamtoro}

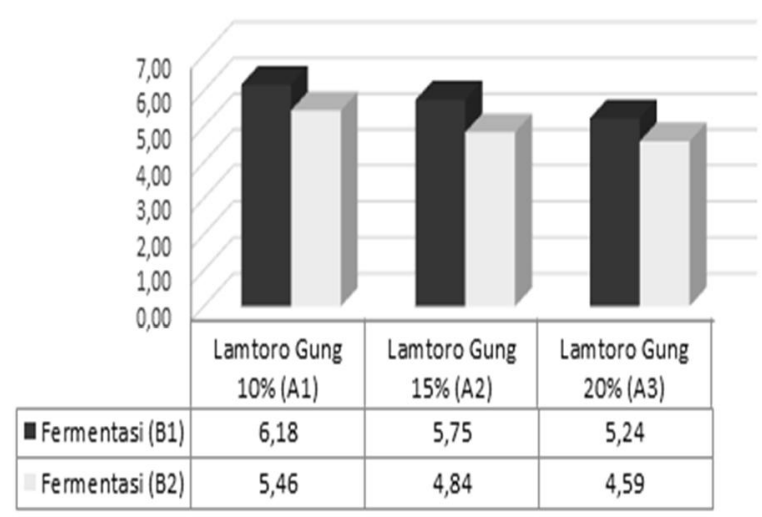

Gambar 3. Rerata kadar lemak (\%) tempe lamtoro

Berdasarkan data pada Gambar 3 kadar lemak tempe lamtoro dengan perlakuan lama fermentasi dan prosentase biji lamtoro gung dapat diketahui bahwa semakin lama waktu fermentasi kadar lemak tempe semakin menurun dan semakin sedikit prosentase biji lamtoro gung yang digunakan maka kadar lemak pada tempe lamtoro juga semakin meningkat hal ini terjadi karena kandungan lemak pada kedelai lebih besar dari pada kandungan protein dalam biji lamtoro gung. Hal ini dikarenakan lemak tidak mudah langsung digunakan oleh mikroba untuk kelangsungan hidup dibandingkan dengan protein dan karbohidrat (Budijanto dkk., 2001).

\section{Kadar Air}

Keberadaan air sangat penting bagi kehidupan umat manusia dan fungsinya tidak dapat digantikan dengan senyawa lain. 
Air berperan untuk menstabilkan suhu tubuh, membawa zat gizi dan sisa metabolisme, pereaksi dan medium reaksi, menstabilkan konformasi biopoler dan memfasilitasi aktivitas makro molekul seperti reaksi enzimatik dan lain-lain (Fardiaz, 1992).

Air pada bahan pangan tidak hanya dimanfaatkan untuk memenuhi kebutuhan manusia, air juga mempunyai peranan yang sangat besar bagi bahan pangan itu sendiri. Keberadaan air dalam bahan pangan sering dihubungkan dengan mutu bahan pangan sebagai pengukur bagian bahan kering atau padatan, penentu indeks kestabilan selama penyimpanan serta penentu mutu organoleptik terutama pada rasa (Fardiaz, 1992).

Tabel 4. Rata-rata kadar air (\%) tempe lamtoro

\begin{tabular}{cclc}
\hline $\begin{array}{c}\text { Lama } \\
\text { Fermentasi }\end{array}$ & $\begin{array}{c}\text { Prosentase } \\
\text { Biji } \\
\text { Lamtoro } \\
\text { Uung }\end{array}$ & $\begin{array}{l}\text { Rerata } \\
\text { Kadar } \\
\text { Air }\end{array}$ & $\begin{array}{c}\text { DMRT } \\
5 \%\end{array}$ \\
\hline \multirow{3}{*}{ 18 Jam } & $10 \%$ & $67,78 \mathrm{~d}$ & 3,28 \\
& $15 \%$ & $65,78 \mathrm{f}$ & 3,22 \\
& $20 \%$ & $62,49 \mathrm{e}$ & 2,98 \\
36 Jam & $10 \%$ & $70,57 \mathrm{f}$ & 3,36 \\
& $15 \%$ & $69,01 \mathrm{e}$ & 3,33 \\
& $20 \%$ & $63,96 \mathrm{~b}$ & 3,13 \\
\hline
\end{tabular}

Histagram rata-rata kadar airpada berbagai perlakuan lama fermentasi dan prosentase biji lamtoro gung disajikan pada Gambar 4.

Berdasarkan analisa kadar air yang dilkukan pada tempe lamtoro diperoleh ratarata kadar air antara $62,49 \%$ sampai 70,57 $\%$ berdasarkan analisa sidik ragam kadar air tempe lamtoro bahwa perlakuan prosentase biji lamtoro gung (A) dan lama fermentasi tempe (B) menunjukkan pengaruh sangat berbeda nyata. Rata - rata kadar protein berbagai kombinasi perlakuan dapat dilihat pada Tabel 4.
Rerata Kadar Air Tempe Lamtoro

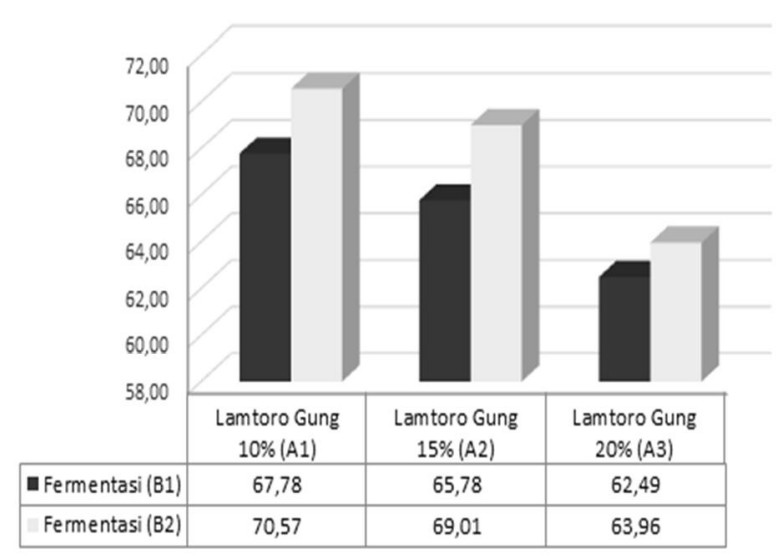

Gambar 4. Rerata kadar air (\%) tempe lamtoro

Gambar 4. menunjukkan bahwa kadar Air tertinggi diperoleh pada kombinasi perlakuan A1B2 (prosentase biji lamtoro gung sebesar $10 \%$ dan lama fermentasi 36 jam) yaitu sebesar 70,57\%, sedangkan kadar air terendah diperoleh pada kombinasi perlakuan A3B1 (prosentase biji lamtoro gung sebesar $10 \%$ dan lama termentas1 i jam) yaitu sebesar $62,49 \%$.

Perlakuan lama fermentasi memberikan pengaruh terhadap kadar air tempe. Dari Gambar 4 dapat dilihat bahwa semakin lama fermentasi maka semakin meningkat kadar airnya. Hal ini terjadi karena selama fermentasi terjadi proses metabolisme dan perombakan senyawa makromolekul menjadi senyawa yang lebih sederhana. Waktu fermentasi merupakan salah satu faktor terpenting penyebab meningkatnya kadar air sehingga dengan meningkatnya waktu fermentasi maka kadar air akan meningkat pula.

Kadar air tempe lamtoro dengan prosentase biji lamtoro gung yang lebih sedikit cenderung lebih tinggi bila dibandingkan dengan prosentase biji lamtoro gung yang lebih tinggi, hal ini terjadi karena kadar air tempe dipengaruhi dari jumlah prosentase kedelai yang digunakan. Pada saat pembuatan tempe, kedelai mengalami hidrasi terutama pada saat perendaman dan perebusan sehingga berat kedelai dapat meningkat karena air akan mudah berdifusi 
kedalam dinding sel kedelai (Steinkraus, 1983).

\section{Organoleptik Rasa}

Menurut Kartika dkk (1988), makanan merupakan gabungan dari berbagai macam rasa bahan-bahan yang digunakan dalam makanan tersebut. De Mann (1989) mendefinisikan flavor atau rasa sebagai rangsangan yang ditimbulkan oleh bahan yang dimakan, yang dirasakan oleh indra pengecap atau pembau, serta rangsangan lainnya seperti perabaan dan penerimaan derajat panas oleh mulut.

Hasil analisa uji organoleptik menyajikan bahwa rata-rata ranking kesukaan panelis terhadap rasa dari perlakuan berbagai kombinasi antara prosentase biji lamtoro gung dan lama fermentasi berkisar antara 3,5\% sampai 4,75 $\%$.

Semakin tinggi rata-rata nilai kesukaan panelis terhadap rasa tempe lamtoro, maka tingkat kesukaan panelis terhadap rasa tempe lamtoro semakin besar. Rata-rata tingkat kesukaan panelis terhadap rasa tempe lamtoro ditunjukkan pada Gambar 5

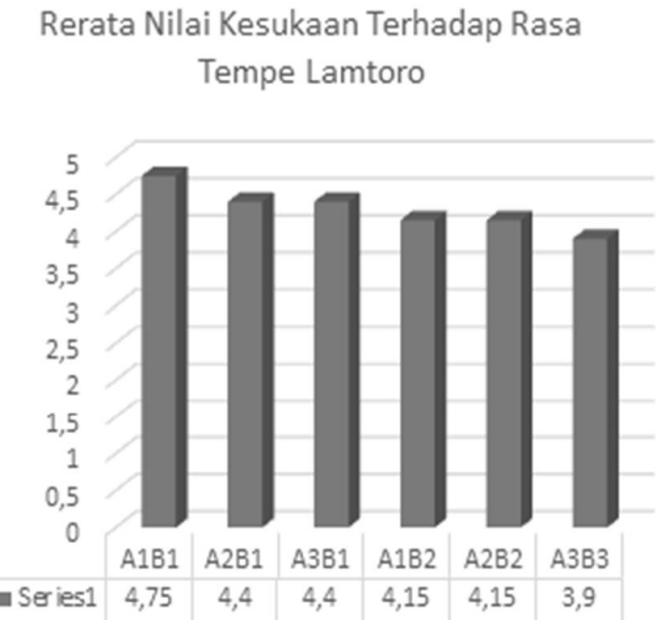

Gambar 5. Rerata organoleptik rasa

Rata-rata nilai kesukaan panelis terhadap rasa tempe lamtoro mempunyai nilai terendah sebesar 3,9\% dari kombinasi A2B2 (prosentase biji lamtoro $20 \%$ dan lama fermentasi 36 jam) sedangkan nilai tertinggi sebesar $4,75 \%$ didapatkan dari kombinasi A1B1 (prosentase biji lamtoro 10 $\%$ dan lama fermentasi 18 jam).

Dari hasil pengamatan dapat disimpulakan bahwa semakin kecil prosentase biji lamtoro gung yang digunakan dan 18 jam lama fermentasi dlakukan maka rasa tempe lamtoro yang dihasilkan semakin disukai panelis, hal ini dikarenakan semakin lama fermentasi akan menciptakan rasa masam pada tempe lamtoro, sehingga semakin lama fermentasi yang dilakukan akan merusak rasa asli pada tempe lamtoro. Sesuai dengan penelitian yang dilakukan bahwa panelis yang telah mencicipi tempe lamtoro dari tiap perlakuan yang berbeda merasakan rasa khas tempe pada lama fermentasi 18 jam dan sekidit masam ketika mencicipi tempe lamtoro pada lama fermentasi 36 jam.

\section{Organoleptik Aroma}

Menurut de Mann (1989), dalam industri pangan pengujian aroma atau bau dianggap penting karena cepat dapat memberikan hasil. Penilaian terhadap produk terkait diterima atau tidaknya suatu produk. Timbulnya aroma atau bau ini karena zat bau tersebut bersifat volatil (mudah menguap). Hasil analisa uji organoleptik menyajikan bahwa rata-rata ranking kesukaan panelis terhadap aroma dari perlakuan berbagai kombinasi antara prosentase biji lamtoro gung dan lama fermentasi berkisar antara 3,55 \% sampai $4,35 \%$.

Semakin tinggi rata-rata nilai kesukaan panelis terhadap aroma tempe lamtoro, maka tingkat kesukaan panelis terhadap aroma tempe lamtoro semakin besar. Rata-rata tingkat kesukaan panelis terhadap aroma tempe lamtoro ditunjukkan pada Gambar 6. 


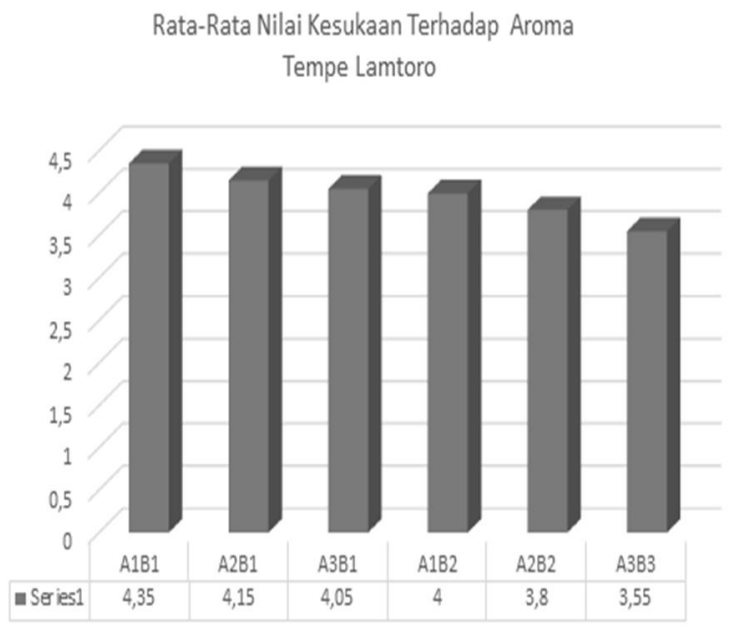

Gambar 6. Rata-rata organoleptik aroma

Rata-rata nilai kesukaan panelis terhadap aroma tempe lamtoro mempunyai nilai terendah sebesar 3,55\% dari kombinasi A3B2 ( prosentase biji lamtoro $20 \%$ dan lama fermentasi 36 jam) sedangkan nilai tertinggi sebesar 4,35 \% didapatkan dari kombinasi A1B1 (prosentase biji lamtoro 10 $\%$ dan lama fermentasi 18 jam).

Dari hasil pengamatan dapat disimpulakan bahwa semakin kecil prosentase biji lamtoro gung yang digunakan dan 18 jam lama fermentasi dlakukan maka aroma tempe lamtoro yang dihasilkan semakin disukai panelis, hal ini dikarenakan semakin lama fermentasi akan menciptakan aroma yang masam pada tempe lamtoro, sehingga semakin lama fermentasi yang dilakukan akan merusak aroma asli pada tempe lamtoro. Sesuai dengan penelitian yang dilakukan bahwa panelis yang telah mencium aroma tempe lamtoro dari tiap perlakuan yang berbeda menghirup aroma khas tempe pada lama fermentasi 18 jam dan sekidit masam ketika menghirup aroma tempe lamtoro pada lama fermentasi 36 jam.

\section{Organoleptik Warna}

Semakin tinggi rata-rata nilai kesukaan panelis terhadap warna tempe lamtoro, maka tingkat kesukaan panelis terhadap warna tempe lamtoro semakin besar. Rata-rata tingkat kesukaan panelis terhadap aroma tempe lamtoro ditunjukkan pada gambar 4.6
Rerata Nilai Kesukaan Terhadap warna Tempe Lamtoro

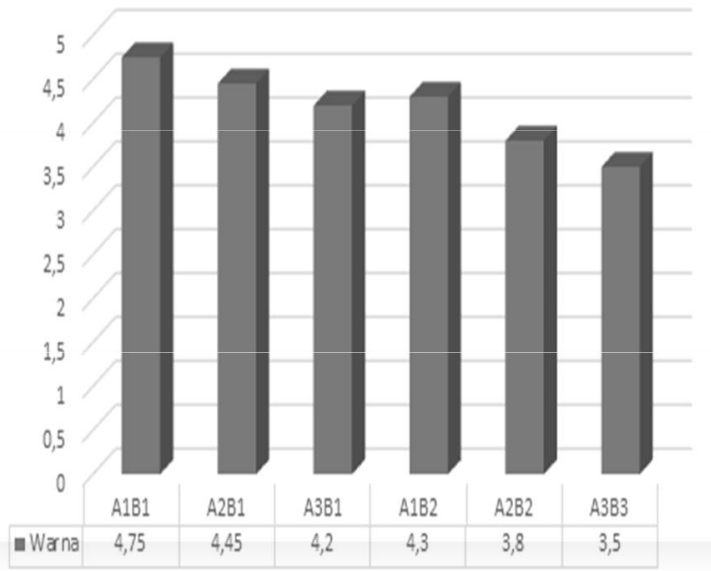

Gambar 7. Rata-rata organoleptik warrna

Rata-rata nilai kesukaan panelis terhadap warna tempe lamtoro mempunyai nilai terendah sebesar 3,5\% dari kombinasi A3B2 (prosentase biji lamtoro $20 \%$ dan lama fermentasi 36 jam) sedangkan nilai tertinggi sebesar 4,75\% didapatkan dari kombinasi A1B1 (prosentase biji lamtoro 10 $\%$ dan lama fermentasi 18 jam).

Dari hasil pengamatan dapat disimpulakan bahwa semakin kecil prosentase biji lamtoro gung yang digunakan dan 18 jam lama fermentasi dlakukan maka warna tempe lamtoro yang dihasilkan semakin disukai panelis, hal ini dikarenakan semakin lama fermentasi akan menciptakan warna kuning kecoklatan pada tempe lamtoro, sehingga semakin lama fermentasi yang dilakukan akan merusak warna kuning cerah dan hijau pada tempe lamtoro. Sesuai dengan penelitian yang dilakukan bahwa panelis yang telah melihat warna tempe lamtoro dari tiap perlakuan yang berbeda melihat warna khas kuning cerah tempe pada lama fermentasi 18 jam dan sekidit kuning kecoklatan ketika melihat warna tempe lamtoro pada lama fermentasi 36 jam.

\section{Organoleptik Tekstur}

Semakin tinggi rata-rata nilai kesukaan panelis terhadap tekstur tempe lamtoro, maka tingkat kesukaan panelis terhadap tekstur tempe lamtoro semakin besar. Ratarata tingkat kesukaan panelis terhadap 
tekstur tempe lamtoro ditunjukkan pada Gambar 8.

\section{Rerata Nilai Kesukaan Terhadap Tekstur Tempe Lamtoro}

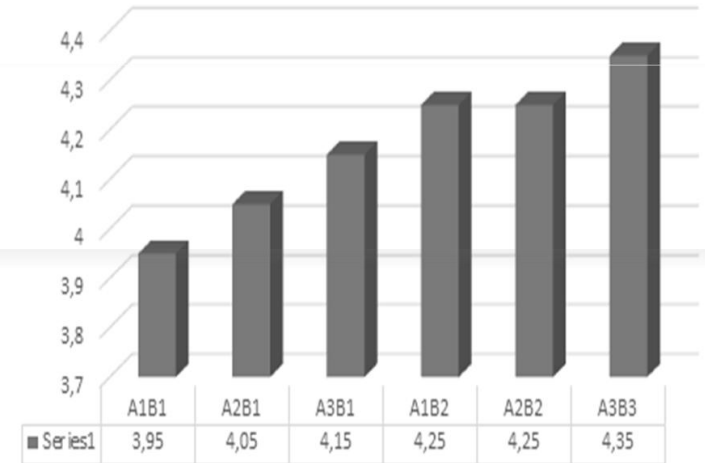

Gambar 8. Rata-rata organoleptik tekstur

Rata-rata nilai kesukaan panelis terhadap tektur tempe lamtoro mempunyai nilai terendah sebesar 3,95\% dari kombinasi A1B1 ( prosentase biji lamtoro $10 \%$ dan lama fermentasi 18 jam) sedangkan nilai tertinggi sebesar 4,35\% didapatkan dari kombinasi A3B2 (prosentase biji lamtoro 20 $\%$ dan lama fermentasi 36 jam).

Dari hasil pengamatan dapat disimpulakan bahwa semakin kecil prosentase biji lamtoro gung yang digunakan dan 18 jam lama fermentasi dlakukan maka tektur tempe lamtoro yang dihasilkan semakin tidak disukai panelis, hal ini dikarenakan semakin lama fermentasi akan menciptakan tekstur yang semakin solid pada tempe lamtoro, sehingga semakin lama fermentasi yang dilakukan tekstur tempe lamtoro akan semakin baik. Sesuai dengan penelitian yang dilakukan bahwa panelis yang telah merasakan tekstur tempe lamtoro dari tiap perlakuan yang berbeda merasakan tekstur tempe pada lama fermentasi 18 jam lebih keras dari pada tekstur tempe lamtoro pada lama fermentasi 36 jam.

\section{Perlakuan Terbaik}

Kombinasi perlakuan terbaik fisikokimia dan organoleptik pada pembuatan tempe lamtoro diperoleh dari perlakuan A1B1 (prosentase biji lamtoro gung $10 \%$ dan lama fermentasi 18 jam) dengan karakteristik sebagai berikut : kadar Air 67,78 \% ; kadar protein 17,27 \% ; kadar lemak 6,18 \% ; kadar karbohidrat 14,51\% ; nilai kesukaan rasa 4,75 (Menyukai); nilai kesukaan aroma 4,35 (Menyukai).

\section{KESIMPULAN DAN SARAN}

\section{Kesimpulan}

1. Berdasarkan hasil uji fisikokimia didapatkan bahwa prosentase biji lamtoro gung terbaik dalam pembuatan tempe lamtoro adalah $10 \%$ dan lama fermentasi terbaik dalam pembuatan tempe lamtoro adalah 36 jam.

2. Berdasarkan hasil uji organoleptik didapatkan bahwa prosentase biji lamtoro gung terbaik dalam pembuatan tempe lamtoro adalah $10 \%$ dan lama fermentasi terbaik dalam pembuatan tempe lamtoro adalah 18 jam.

3. Berdasarkan hasil uji fisikokimia dan organoleptik didapatkan bahwa kombinasi prosentase biji lamtoro gung dan lama fermentasi terbaik pada pembuatan tempe lamtoro adalah prosentase sebesar $10 \%$ dan lama fermentasi 18 jam dengan kualitas sebagai berikut : kadar Air 67,78\% ; kadar protein $17,27 \%$; kadar lemak 6,18 $\%$; kadar karbohidrat $14,51 \%$; nilai kesukaan rasa 4,75 (menyukai); nilai kesukaan aroma 4,35 (menyukai); nilai kesukaan warna 4,75 (menyukai); nilai kesukaan tekstur 3,95 (netral).

\section{Saran}

Perlunya dilakukan penelitian lanjutan terutama tentang biji-biji seperti kacang merah, kacang polong dan beras yang bisa dijadikan tempe yang mempunyai kualitas lebih baik dari tempe lamtoro sebagai usaha diversifikasi pangan.

\section{DAFTAR PUSTAKA}

.Anonymous,2015b.Lamtoro. http://id.wikipedia.org/wiki/Lamtoro. Diakses pada tanggal 12 Maret 2015. 
AOAC. 2005. Official methods of analysis. Association of official analysis chemistry. Wasinghton

Budijanto, Andarwulan, N. dan Herawati, D. 2001. Bab praktikum kimia dan teknologi lipida. Departemen Teknologi Pangan dan Gizi, Fakultas Teknologi Pertanian, Institut Pertanian Bogor.

DeMann, J. M. 1989. Principle of food chemistry. Penerjemah; Kosasih Padmawinata. Institut Teknologi Bandung, Bandung.

Fardiaz, D., Andarwulan, N. Wijaya, C.H. dan Puspita, N.L. 1992. Teknik analisis sifat kimia dan fungsional komponen pangan. Pusat Antar Universitas Pangan dan Gizi IPB, Bogor.

Kartika, B., Hastuti P., dan Supartono, W. 1988. Pedoman uji indrawi bahan pangan. Pusat Antar Universitas Pangan dan Gizi UGM, Yogyakarta.

Kasmidjo, R.B. $1990 . \quad$ Tempe: mikrobiologi dan biokimia pengolahan serta pemanfaatannya. Yogyakarta: PAU Pangan dan Gizi.
Komari. 1999. Proses fermentasi biji lamtoro gung dengan Rhizopus oryzae. Jurnal Mikrobiologi Indonesia 4 (1): 19-21.

Marwanti. 2012. Diversifikasi pengolahan bahan pangan lokal. http://staff.uny.ac.id/sites/defa ult/files/Diversifikasi.pdf. Diakses pada tanggal 26 Februari 2015.

Rahayu, E.S., Indrati, R. Utami, T. Harmayani, E. dan Cahyanto, M.N. 2005. Bahan pangan hasil fermentasi. Yogyakarta: PAU UGM.

Santoso. 2005. Teknologi pengolahan kedelai. Fakultas Pertanian Universitas Wdyagama,Malang.

Steinkraus, K.H., 1983. Indonesian tempeh and related fermentation. Dalam: Handbook of Indigenous Fermented Foods. UGM, Yogyakarta.

Winarno, F.G. 2004. Kimia pangan dan gizi. PT. Gramedia Pustaka Utama. Jakarta. 